\title{
CARDIORESPIRATORY FUNCTION OF PATIENTS WITH ADOLESCENT IDIOPATHIC SCOLIOSIS
}

\author{
FUNÇÃO CARDIORRESPIRATÓRIA DE PACIENTES COM ESCOLIOSE IDIOPÁTICA \\ DO ADOLESCENTE
}

\section{FUNCIÓN CARDIORRESPIRATORIA DE PACIENTES CON ESCOLIOSIS IDIOPÁTICA DEL ADOLESCENTE}

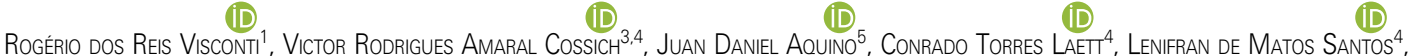

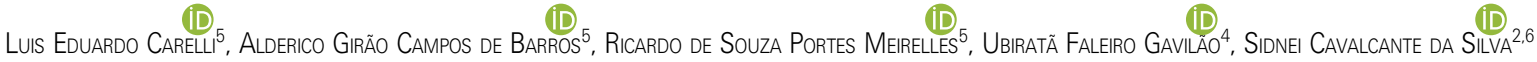 \\ 1. Instituto Nacional de Traumatologia e Ortopedia (INTO), Teaching and Research Division (DIENP), Graduate Program in Applied Musculoskeletal System Sciences, \\ Rio de Janeiro, RJ, Brazil. \\ 2. Instituto Nacional de Traumatologia e Ortopedia (INTO), Exercise Physiology Research Laboratory, Research Division, Rio de Janeiro, RJ, Brazil. \\ 3. Universidade Federal do Rio de Janeiro (UFRJ), Escola de Educação Física e Desportos (EEFD), Biomechanics Laboratory, Department of Biosciences, Rio de Janeiro, RJ, Brazil. \\ 4. Instituto Nacional de Traumatologia e Ortopedia (INTO), Neuromuscular Research Laboratory, Research Division, Rio de Janeiro, RJ, Brazil. \\ 5. Instituto Nacional de Traumatologia e Ortopedia (INTO), Spine Surgery Center, Rio de Janeiro, RJ, Brazil. \\ 6. Graduate Program in Applied Musculoskeletal System Sciences - Universidade Salgado de Oliveira - Rio de Janeiro, RJ, Brazil.
}

\begin{abstract}
Objective: Adolescent idiopathic scoliosis (AIS) is a spinal deformity that can cause cardiorespiratory dysfunction, contributing to decreases in tolerance for aerobic exercise (TAE) and in functionality. The objective is to assess the TAE and lung capacity of patients who underwent corrective AIS surgery in the pre- (PRE) and postoperative (POST) periods. Methods: Sixty individuals, $P R E(n=30$, age: $18.5 \pm 2.4$ years) and POST ( $n=30$, age: $24.5 \pm 4.5$ years), participated in the study. The forced vital capacity (FVC), the forced expiratory volume in the first second (FEV1) and the FEV1/FVC ratio, as well as the maximum inspiratory and expiratory pressure were verified. The TAE was assessed by the distance travelled in the 6-minute walk test (6MWT), together with blood pressure, heart rate, respiratory rate and peripheral oxygen saturation measured at the beginning and at the end of the test. Results: A mild restrictive pattern in lung function and reduced expiratory muscle strength were observed in both groups, but with no difference between the PRE and POST groups. No difference was found between the PRE $(534 \pm 67.1 \mathrm{~m})$ and POST $(541 \pm 69.5 \mathrm{~m})$ groups for the distance travelled in the 6MWT, though both were below the predicted percentage $(82.8 \pm 10.0 \%$ and $84.8 \pm 10.9 \%$, respectively). Hemodynamic and respiratory changes caused by the $6 \mathrm{MWT}$ were observed, except for the peripheral oxygen saturation. Conclusion: The results suggest that even after surgical correction, patients with AIS continue to have low TAE. Level of evidence III; Therapeutics Study - Investigation of Treatment Results / Case-control study.
\end{abstract}

Keywords: Scoliosis; Exercise Tolerance; Respiratory Function Tests; 6-Minute Walk Test.

\section{RESUMO}

Objetivo: A escoliose idiopática do adolescente (EIA) é uma deformidade da coluna que pode ocasionar disfunções cardiorrespiratórias, contribuindo para a diminuição da tolerância ao exercício aeróbio (TEA) e da funcionalidade. O objetivo é avaliar a TEA e a capacidade pulmonar em pacientes no pré (PRE) e pós-operatório (PÓS) de correção da ElA. Métodos: Participaram 60 indivíduos PRÉ ( $n=30$, idade: 18,5 $\pm 2,4$ anos) e PÓS ( $n=30$, idade: $24,5 \pm 4,5$ anos). A capacidade vital forçada (CVF), o volume expiratório forçado no primeiro segundo (VEF1) e a razão VEF1/CVF, assim como as pressões inspiratória e expiratória máximas, foram verificados. A TEA foi avaliada pela distância percorrida no teste de caminhada de 6 minutos (TC6), acompanhado de medidas de pressão arterial, frequência cardíaca, frequência respiratória e saturação periférica de oxigênio no início e no final do teste. Resultados: Um padrão restritivo leve na função pulmonar e força da musculatura expiratória reduzida foram observados em ambos os grupos, mas sem diferença entre PRÉ e PÓS. Não foi encontrada diferença entre PRÉ $(534 \pm 67,1 \mathrm{~m})$ e PÓS $(541 \pm 69,5 \mathrm{~m})$ para a distância percorrida no TC6, abaixo do predito para ambos os grupos (82,8 $\pm 10,0 \%$ e 84,8 \pm 10,9\%, respectivamente). Foram observadas alterações hemodinâmicas e respiratórias provocadas pelo TC6, exceto para a saturação periférica de oxigênio. Conclusões: Os resultados sugerem que mesmo após a correção cirúrgica os pacientes com ElA continuam apresentando baixa TEA. Nível de evidência III; Estudos terapêuticos - Investigação dos Resultados do Tratamento / Estudo de caso-controle.

Descritores: Escoliose; Tolerância ao Exercício; Testes de Função Respiratória; Teste de Caminhada de 6 Minutos.

\section{RESUMEN}

Objetivo: La escoliosis idiopática del adolescente (EIA) es una deformidad de la columna que puede causar disfunciones cardiorrespiratorias, contribuyendo para la disminución de la tolerancia al ejercicio aeróbico (TEA) y de la funcionalidad. El objetivo es evaluar la TEA y la capacidad pulmonar en pacientes en el pre (PRE) y postoperatorio (POS) de corrección de la EIA. Métodos: Participaron 60 individuos

Study conducted at the Instituto Nacional de Traumatologia e Ortopedia (INTO), Rio de Janeiro, RJ, Brazil.

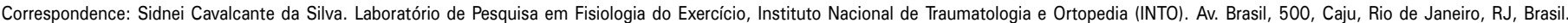
20940-070.sydneys@uol.com.br 
PRE ( $n=30$, edad: $18,5 \pm 2,4$ años) y POS ( $n=30$, edad: $24,5 \pm 4,5$ años). Fueron verificadas la capacidad vital forzada (CVF), el volumen espiratorio forzado en el primer segundo (VEF1) y la razón VEF1/CVF, así como las presiones inspiratoria y espiratoria máximas. La TEA fue evaluada por la distancia recorrida en el test de caminata de 6 minutos (TC6), acompañado de mediciones de presión arterial, frecuencia cardíaca, frecuencia respiratoria y saturación de oxígeno al inicio y al final del test. Resultados: Fueron observados un patrón restrictivo leve y fuerza muscular espiratoria reducida en ambos grupos, pero sin diferencia entre PRE y POS. No fue encontrada diferencia entre PRE (534 $\pm 67,1 \mathrm{~m})$ y POS $(541 \pm 69,5 \mathrm{~m})$ para la distancia recorrida en el TC6, por debajo de los predicho para ambos grupos $(82,8 \pm 10,0 \%$ y $84,8 \pm 10,9 \%$, respectivamente). Se observaron alteraciones hemodinámicas y respiratorias provocadas por el TC6, excepto para la saturación periférica de oxígeno. Conclusiones: Los resultados sugieren que incluso después de la corrección quirúrgica, los pacientes con EIA continúan presentando baja TEA. Nivel de evidencia III; Estudios Terapéuticos - Investigación de los Resultados del Tratamiento / Estudio de caso-control.

Descriptores: Escoliosis; Tolerancia al Ejercicio; Pruebas de Función Respiratoria; Prueba de Paso de 6 Minutos.

\section{INTRODUCTION}

Scoliosis is a three-dimensional spinal deformity, defined as a lateral deviation in the frontal plane of more than $10^{\circ}$, measured by the Cobb method using panoramic anteroposterior (AP) radiography of the spine in the orthostatic position, with the presence of vertebral rotation. ${ }^{1}$ In addition to lateral deviation in the frontal plane, patients with scoliosis present rectification of the spine in the sagittal plane and rotation of the vertebrae in the axial plane, causing changes to rib cage geometry. ${ }^{2}$ Adolescent idiopathic scoliosis (AIS) accounts for approximately $80 \%$ of all types of scoliosis. ${ }^{3}$ There is a predominance among females and of rigid curves with the thoracic apex to the right. ${ }^{4}$ There is evidence of association between the degree of curvature and compromise of pulmonary function. ${ }^{5,6}$ Newton et al. ${ }^{5}$ studied 631 patients with AIS and found a decline in pulmonary function when the primary curve exceeded $70^{\circ}$. If, at the end of skeletal maturation, the degree of scoliosis reaches critical values, defined by most authors as between 30 and $50^{\circ},{ }^{7}$ there is an increased risk of health issues in adulthood, with a drop in the quality of life, esthetic deformity, pain and progressive functional limitation. ${ }^{8}$

The changes encountered in the ventilatory mechanics and functional capacity of AIS patients can be attributed to distortion of the rib cage caused by vertebral rotation, with a decrease in its sagittal diameter and its compliancy, ${ }^{9}$ impairing normal lung development during the period of rapid growth that occurs during adolescence and resulting in a restrictive ventilatory disorder due to a reduction in the space for normal alveolar growth. ${ }^{10}$

Surgical treatment of scoliosis is indicated when patients have curves of more than $50^{\circ}, 11$ since when untreated, $68 \%$ of these curves progress after skeletal maturation. ${ }^{12}$ Although AIS correction surgery promotes an improvement in structural deformity and the appearance of patients, the long-term effects of surgery on lung function remains unclear, given that the literature has not shown agreement among the reported results. ${ }^{13,14}$ One of the factors responsible for the discrepancy would be the different surgical techniques used in the studies. ${ }^{14}$

It is known that patients with AIS commonly have a decreased tolerance for physical exercise. ${ }^{15-17}$ The causes of this limitation on physical exercise are not yet fully explained. ${ }^{15}$ Ventilatory restriction and the subsequent lack of cardiovascular conditioning are commonly accepted. ${ }^{15,16}$ In this context, little is known about the effect of deformity correction surgery on exercise tolerance in AIS patients. ${ }^{18-20}$ Lenke et al. ${ }^{18}$ were the first to evaluate ventilatory efficiency during physical exercise in patients with AIS submitted to deformity correction surgery and found no improvement in ventilatory efficiency in most patients. Subsequently, Jeans et al. ${ }^{19}$ and Lorente et al. ${ }^{20}$ also observed low cardiorespiratory tolerance for maximum physical exercise and no improvement following corrective surgery.

Bearing in mind that walking is one of the main activities of daily life, walk tests have been proposed to measure patient state or functional capacity. ${ }^{21}$ Its main advantages are its simplicity, the minimal technological requirements, and the low operating cost. ${ }^{21}$ The distance covered in a 6-minute walk test (6MWT) has been used to stratify surgical risk in lung cancer patients who are candidates for lobectomy and patients who will undergo major non-cardiac surgery. ${ }^{22-23}$ Being so, our objective was to verify the tolerance for aerobic exercise of AIS patients, in a cross-sectional study, by means of pre- and postoperative 6MWTs, and its relationship with lung function.

\section{METHODS}

\section{Participants}

A total of 60 volunteers of both sexes, aged between 15 and 35 years, were selected for the study, since most of the patients diagnosed with AIS in the outpatient clinic of the Spine Diseases Center of the Instituto Nacional de Traumatologia e Ortopedia (INTO) fall into this age group. The volunteers were recruited consecutively by invitation via telephone call or letter. Thirty patients with AIS who were on the waiting list for deformity correction surgery from January 2015 to June 2018 (PRE Group) and 30 patients who underwent posterior vertebral arthrodesis from June 2012 to September 2018, with a minimum postoperative follow-up of one year (POST Group), were located and/ or agreed to participate in the study.

The magnitude of the curves was measured using the Cobb method (in the frontal "AP" and sagittal "P" T5-T12 planes). ${ }^{24}$ In both groups, patients with scoliosis with Cobb angle $>40^{\circ}$ who had been indicated for surgical correction were included. For both groups, the exclusion criteria used were the cognitive inability to understand the procedures, any other physical deformity that made conducting the tests impossible, the presence of a prior history of pulmonary or cardiological pathologies, and previous participation in rehabilitation programs in the last six months or in organized sports. All participants and/or their legal guardians were informed about the project goals via the informed consent form and a term of consent for underage patients. This study was previously approved by the Institutional Review Board (CAAE: 2.925.957) as per National Health Council Resolution no. 466 of 12/12/2012.

\section{Data collection}

Data collection was conducted on a single day for each participant, always in the morning. Following informed consent, the IPAQ questionnaire (International Physical Activity Questionnaire) ${ }^{25}$ was administered in order to verify the volume of the participant's weekly physical activity. Next, the following hemodynamic and respiratory measurements were taken from the volunteer at rest: systolic blood pressure (SBP), diastolic blood pressure $(\mathrm{DBP})$, heart rate $(\mathrm{HR})$, respiration rate $(\mathrm{RR})$ and peripheral oxygen saturation $\left(\mathrm{SpO}_{2}\right)$. Body morphology was evaluated using bioelectric impedance analysis, and anthropometric measurements, including total body mass, height and half-arm span, were taken. Subsequently, lung function was assessed by spirometry and respiratory muscle strength was measured by manovacuometry. Then, the 6MWT was conducted and the hemodynamic and respiratory variables were measured again before and immediately after the end of the test. At this point, the subjective perception of effort was measured by means of the Borg Scale (Borg CR-10). ${ }^{26}$

\section{Anthropometric measurements}

A Lider ${ }^{\circledR}$ digital scale, model P150C (São Paulo, Brazil), was used to measure total body mass. Height was measured with an 
anthropometer from Ghrum Polar Manufacture Instruments ${ }^{\circledR}$ (Geneva, Switzerland). The half-arm span was measured using a Sanny ${ }^{\circledR}$ anthropometric measuring tape (São Paulo, Brazil). Both height and arm span could be affected, depending on the degree of vertebral deformity of the patients. To minimize the effect of deformity on the arm span, we used the half-arm span measurement multiplied by two to calculate the arm span. Height was estimated by dividing the arm span 1.03 for the women and by 1.06 for the men. ${ }^{27}$ To assess body composition, a tetrapolar bioimpedance device, model 312 from Byodinamics Corp $^{\circledR}$ (Shoreline, USA) was used. The fat percentage and lean body mass values were obtained using equation provided by the equipment. The body mass index (BMI) was calculated by dividing body mass by height squared.

\section{Measurement of hemodynamic and respiratory variables}

Blood pressure (BP) was measured using digital apparatus, model HEM-7113 - ORON ${ }^{\circledR}$ (Kyoto, Japan). HR was obtained using Polar monitor, model FT1 - Polar Electro Oy ${ }^{\circledR}$ (Kempele, Finland). $\mathrm{SpO}_{2}$ was measured using pulse oximeter, model AT101 - Bioland ${ }^{\circledR}$ (Alvital Technology Corporation, Taiwan). RR was measured for 60 seconds, counting complete breath cycles (inhalation and exhalation).

\section{Lung function test (Spirometry)}

A Fleisch-type pneumotachometer, model KoKo Sx1000 nSpireHealth ${ }^{\circledR}$ (Longmont, USA), was used to perform spirometry as per the ATS/ERS recommendations. ${ }^{28}$ The following parameters were measured and expressed as percentages of the predicted values: forced vital capacity (FVC), forced expiratory volume in one second $\left(\mathrm{FEV}_{1}\right)$ and the $\mathrm{FEV}_{1} / \mathrm{FVC}$ ratio. The theoretical values predicted by Knudson et al. were used. ${ }^{29}$

\section{Respiratory muscle strength (Manovacuometry)}

Maximum static respiratory pressure measurements were also taken according to the Brazilian Society of Pneumology guidelines, ${ }^{30}$ using an analog manovacuometer - Wika ${ }^{\circledR}$ (São Paulo, Brazil), with a scale between - 150 and $+150 \mathrm{cmH}_{2} \mathrm{O}$ to measure maximum inspiratory pressure (MIP) and maximum expiratory pressure (MEP). The results were expressed as a percentage of the predicted values for the adult Brazilian population. ${ }^{31}$

\section{6-minute walk test (6MWT)}

For the 6MWT, the participant was encouraged to walk as fast as possible for 6 minutes along a straight and level 30-meter corridor with a hard surface, marked at 3-meter intervals. The procedure for performing the test followed ATS recommendations. ${ }^{21}$ The theoretical values predicted for the Brazilian population were used as a reference for the distances covered. ${ }^{32}$

\section{Radiographs}

Panoramic spinal radiographs were performed in AP and $P$ planes with the patient in orthostasis, using $X$-ray equipment, model RADspeed MF - Shimadzu do Brasil ${ }^{\circledR}$ (São Paulo, Brazil). As all the radiological images used in the study were included in each patient's medical file, it was not necessary to expose the volunteers to radiation during the project. Cobb angles were measured by a single orthopedic surgeon (JDA).

\section{Analysis of the results}

Descriptive statistics (mean $\pm \mathrm{SD}$ ) were used. The sample distribution was verified by the Shapiro-Wilk test. Separate independent-measures t-tests or Mann-Whitney U tests were used to compare the anthropometric variables, the preoperative Cobb angle, lung function and the 6MWT distance covered of the groups. Differences in physical activity levels between the groups were compared with the Chi-squared test. To verify differences in the hemodynamic and respiratory variables between the beginning and the end of the 6MWT, a mixed model ANOVA was used, in which the group [PRE and POST] was used as an independent factor and the initial and final measurements [INITIAL and FINAL] of the hemodynamic and respiratory variables were used as dependent factors. When necessary, the Bonferroni post hoc test was used and the level of statistical significance adopted was $p \leq 0.05$.

\section{RESULTS}

Table 1 shows demographic and anthropometric data and radiological findings. A total of 24 women and 6 men participated in each of the PRE and POST study groups. Significant differences were observed between the groups only for age $(p<0.001)$ and preoperative Cobb angle $(p=0.004)$. No significant differences were observed in the other study variables. (Table 1) No significant differences were observed ( $p=0.74$ ) in the level of physical activity between the groups (IPAQ - PRE: 3 low, 19 moderate and 8 high subjects and POST: 5 low, 17 moderate and 8 high subjects).

The spirometry and respiratory pressure variables are shown in Table 2. Both groups demonstrated a mild restrictive pattern in lung function. The evaluation of respiratory pressures showed a reduction in the strength of the expiratory muscles as compared to the predicted reference values. No significant differences between the PRE and POST groups were identified for any of the study variables. (Table 2)

Table 1. Demographic, anthropometric and preoperative radiological data of the patients with adolescent idiopathic scoliosis.

\begin{tabular}{c|c|c|c}
\hline Variable & PRE & POST & p-value \\
\hline Sample [female (\%)] & $24(80)$ & $24(80)$ & --- \\
\hline Age (years) & $18.5 \pm 2.4^{*}$ & $24.5 \pm 4.5$ & $<0.001$ \\
\hline Height $(\mathrm{cm})$ & $162.3 \pm 7.6$ & $165.0 \pm 7.9$ & 0.83 \\
\hline Total body mass $(\mathrm{kg})$ & $54.1 \pm 11.0$ & $59.4 \pm 14.8$ & 0.12 \\
\hline Lean body mass $(\mathrm{kg})$ & $38.5 \pm 9.3$ & $42.3 \pm 10.2$ & 0.14 \\
\hline Body fat $(\%)$ & $29.0 \pm 6.6$ & $28.1 \pm 8.8$ & 0.65 \\
\hline BMl $\left(\mathrm{kg} / \mathrm{m}^{2}\right)$ & $20.5 \pm 3.5$ & $21.8 \pm 5.2$ & $0.33^{\#}$ \\
\hline Cobb AP $\left(^{\circ}\right)$ & $60.5 \pm 16.7$ & $67.1 \pm 19.9$ & $0.27^{\#}$ \\
\hline Cobb P T5-T12 $\left(^{\circ}\right)$ & $13.6 \pm 7.1^{*}$ & $19.5 \pm 10.7$ & $0.004^{\#}$ \\
\hline
\end{tabular}

Preoperative group (PRE). Postoperative group (POST). Body mass index (BMI). Curve magnitude (Cobb). Frontal plane (AP). Sagittal plane (P). When values were not specified, they were described as mean \pm standard deviation. *Significantly different between groups. When flagged with \#, the as mean \pm standard deviation. *Significantly different between groups. When flagged with \#, the
p-value was obtained with the nonparametric Mann-Whitney U test; otherwise, with the independent-measures t-test.

Table 2. Spirometry and respiratory pressures of the patients with adolescent idiopathic scoliosis.

\begin{tabular}{c|c|c|c}
\hline Variables & PRE & POST & p-value \\
\hline \multicolumn{4}{|c}{ Spirometry } \\
\hline $\mathrm{FVC} \mathrm{( \% )}$ & $78.6 \pm 14.2$ & $73.3 \pm 18.2$ & 0.20 \\
\hline $\mathrm{FEV}(\%)$ & $73.9 \pm 14.9$ & $69.2 \pm 17.3$ & 0.26 \\
\hline $\mathrm{FEV}_{1} / \mathrm{FVC}(\%)$ & $94.8 \pm 7.9$ & $95.8 \pm 11.6$ & 0.72 \\
\hline \multicolumn{4}{c}{ Respiratory pressures } \\
\hline $\mathrm{PI}_{\max }(\%)$ & $90.6 \pm 30.2$ & $101.8 \pm 29.4$ & $0.10^{\#}$ \\
\hline $\mathrm{PE}_{\max }(\%)$ & $76.8 \pm 19.4$ & $85.6 \pm 25.4$ & $0.12^{\#}$
\end{tabular}

Preoperative group (PRE). Postoperative group (POST). Forced vital capacity (FVC). Forced expiratory volume in 1 second $\left(F E V_{1}\right)$. Ratio $\left(F E V_{1} / F V C\right)$. Maximum inhalation pressure $\left(\mathrm{PI}_{\max }\right)$. Maximum exhalation pressure $\left(\mathrm{PE}_{\max }\right)$. Values expressed as a percentage of the predicted values. Mean \pm standard deviation of the sample. * Significant difference. Values were described as mean \pm standard deviation. When flagged with \#, the p-value was obtained with the nonparametric Mann-Whitney U test; otherwise, with the independent-measures t-test.

No significant differences between the PRE and POST groups were observed either in the distance covered (PRE $534 \pm 67.1 \mathrm{~m}$; POST $541 \pm 69.5 \mathrm{~m} ; \mathrm{p}=0.07$ - Figure 1 ) or in the predicted percentage of the distance covered (PRE $82.8 \pm 10.0 \%$; POST $84.8 \pm$ $10.9 \% ; p=0.47$ ), with both groups below the predicted value. This trend was also observed in the Borg CR10 at the end of the 6MWT (PRE $3.0 \pm 1.1 ;$ POST $2.8 \pm 0.8 ; p=0.71$ ).

Figure 2 illustrates the hemodynamic and respiratory variable values of both groups, before and immediately after the 6MWT. Significant effects were observed for the 6MWT moments for HR 
(group: $p=0.23$; moment: $p<0.001$; interaction: $p=0.38$ ), SBP (group: $p=0.81$; moment: $p<0.001$; interaction: $p=0.11$ ), DBP (group: $p=0.67$; moment: $p<0.001$; interaction: $p=0.24$ ) and $R R$ (group: $p=0.42$; moment: $p<0.001$; interaction: $p=0.98$ ). Only for $\mathrm{SpO}_{2}$ (group: $\mathrm{p}=0.15$; moment: $\mathrm{p}=0.91$; interaction: $\mathrm{p}=0.33$ ) were no differences shown for either the group or the moment.

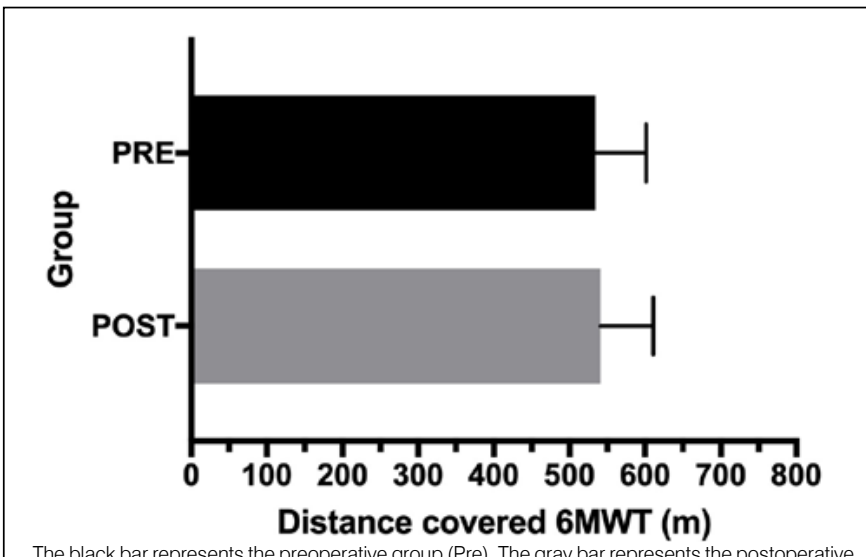

group (Post) 6-minuts the preoperative group (Pre). The gray bar represents the postoperativen No differences were found between the groups.

Figure 1. Distance covered in the 6MWT by the preoperative and postoperative groups.

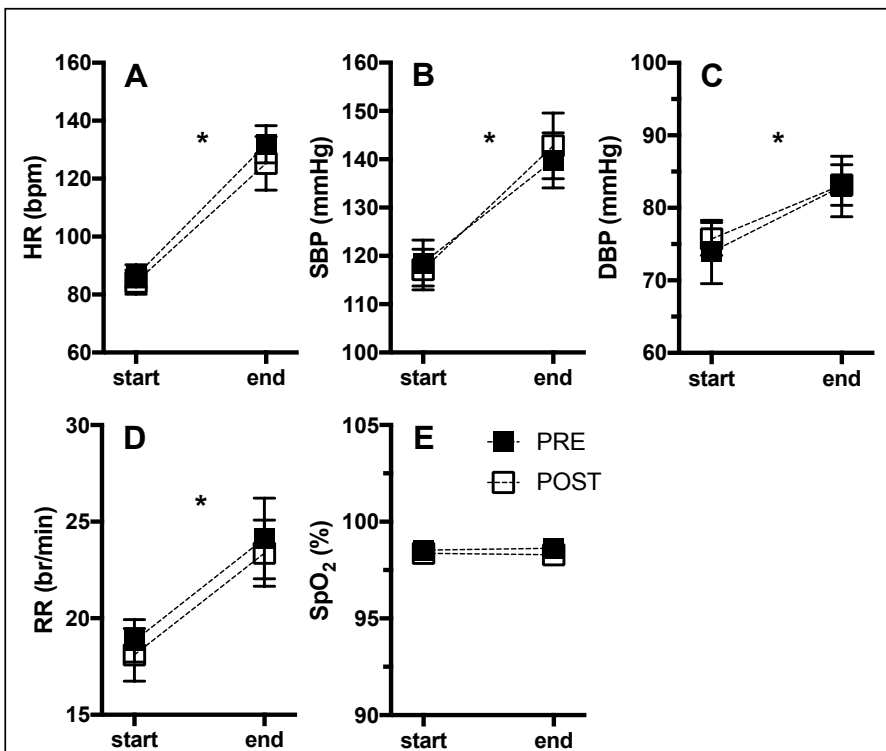

Black squares represent the preoperative group (Pre). White squares represent the postoperative group (Post). Values expressed as mean \pm standard deviation. Heart rate (HR). Systolic blood pressure (SBP). Diastolic blood pressure (DBP). Respiratory rate (RR). Peripheral oxygen saturation (SpO2). Variables measured before starting the 6MWT (Initial). Variables measured right after completion of the GMWT (Final) * Significant difference between the Initial and Fin

Figure 2. Hemodynamic and respiratory variables at the initial and final moments of the 6MWT in both groups.

\section{DISCUSSION}

This study investigated tolerance for aerobic exercise through the 6-minute walk test, using the distance covered in meters and its effect on the hemodynamic and respiratory variables as the criteria, in individuals of both sexes with AIS under both pre- and postoperative conditions, associated with spirometric and respiratory pressure variables. The main finding was that, even having undergone AIS correction surgery, the POST group did not demonstrate results superior to those of the PRE group for any of the variables studied.

It has been observed that morbidity and mortality are associated with impaired lung function in individuals with AIS and both evolve together with spinal deformity. ${ }^{5,35}$ Thus, evaluating the cardiopulmonary efficiency and tolerance for aerobic exercise of individuals with AIS while walking become extremely important for a better understanding of the effects of the disease and surgical treatment. Both groups had a mild restrictive ventilatory pattern (FVC $>70 \%$ ), which was expected, since the curves in both groups were around 60$70^{\circ}$, although curves $>70^{\circ}$ cause greater impact on lung function. ${ }^{33}$ Additionally, low MEP values were found, indicating a decrease in expiratory muscle strength, corroborating the findings of Martínez-Llorens et al., ${ }^{34}$ who observed a decrease in both MEP and MIP and attributed the decrease in tolerance for exercise in AIS patients to generalized muscle dysfunction. However, we did not observe any significant differences between the groups in distance covered or in the hemodynamic and respiratory variables during execution of the 6MWT. However, we observed a difference in the hemodynamic and respiratory variables between the moments (INITIAL and FINAL) for both groups, (Figure 2) which was expected, given that in the FlNAL moment the participants were affected by the metabolic stress caused by the exercise, regardless of their physical conditioning. Unlike the other variables analyzed, no significant difference in $\mathrm{SpO}_{2}$ was observed, either between the groups or the moments (Figure $2 \mathrm{E}$ ) and we believe that this $\mathrm{SpO}_{2}$ response may be justified by the intensity of the activity performed (sub-maximum test) and by the fact that the groups did not present severe impairment of lung function ( $F E V_{1}$ less than $50 \%$ of the predicted value). ${ }^{28}$

The IPAQ aims to verify the amount of physical activity performed by an individual in a week, classifying their physical activity level as low, moderate or high. ${ }^{25}$ Interestingly, no significant difference in physical activity level was observed between the groups. One might expect that the POST group would be more active, having already been submitted to a surgical procedure, which in theory would guarantee them more autonomy and ease in practicing physical activities. However, data presented leads us to speculate that perhaps the protective habits acquired in the preoperative period, the lack of opportunities for the practice of physical activities and/or even sedentary behavior may have contributed to the results found. Unfortunately, we did not find any study in the literature that had used the IPAQ in a population similar to ours for possible comparisons or that could help explain our findings.

Seeking to understand the pre- and postoperative tolerance of individuals with AIS for aerobic exercise, it was possible to verify only three studies in the literature. ${ }^{18-20}$ These studies did not report improved tolerance for exercise following AIS deformity correction surgery during two years of postoperative follow-up, and for this analysis the authors used the cardiopulmonary exercise test to measure the maximum oxygen consumption $\left(\mathrm{VO}_{2} \mathrm{max}\right)$ of the participants. The research that most resembles our study was developed by Araujo et al., ${ }^{36}$ in which the authors evaluated tolerance for exercise in AIS patients in the postoperative period with a control group of healthy adolescents, using the incremental shuttle walk test (ISWT). In their findings, the AIS patients presented a significant reduction in postoperative exercise capacity associated with reduced lung function, residual spinal curvature and lack of cardiovascular conditioning. There are few studies dedicated to understanding the effect of surgery on the aerobic condition of individuals with AIS. It is worth mentioning that none of the works published to date studied groups in the pre- and postoperative periods in the same experiment using a simple walk test that mimics daily functional needs, combined with the easy to obtain hemodynamic and respiratory variables. Thus, these data can be of great value to both the preoperative care of AIS patients and clinical follow-up in a postoperative rehabilitation program, focused on better utilization of the benefits of this intervention in improving the aerobic condition, essential to the execution and autonomy of daily activities.

The cross-functional study design has its limitations by restricting the conclusions we can reach about our results, due to the fact that we are evaluating groups with similar characteristics, (Table 1) but made up of different individuals, thus limiting direct evidence of the effects of 
correction surgery. However, it is an excellent opportunity to advance knowledge about a topic like the influence of vertebral arthrodesis on the aerobic condition of individuals with AIS, which is in the very early stages of information gathering. Another limitation of this study was the fact that we did not perform an analysis of collected gases $\left(\mathrm{O}_{2}\right.$ and $\left.\mathrm{CO}_{2}\right)$ during the 6MWT (ergospirometry), which could have contributed to the discussion about the response of hemodynamic and respiratory variables during the test. However, the data presented here offer a new perspective for the achievement of longitudinal studies enhanced by metabolic analysis of the expired gases together with the assessment of the hemodynamic and respiratory variables.

\section{CONCLUSION}

No difference was observed between the two study groups in the tolerance for exercise during the 6-minute walk test, suggesting that, even after surgical correction, patients with AIS continue to have low tolerance for aerobic exercise. We believe that to improve lung function and functional capacity, encouraging exercises with aerobic activities is perhaps a useful strategy for better preoperative preparation in both groups. In addition, it will enhance the benefits that corrective surgery can bring, increasing the autonomy and functionality of these patients.

\section{ACKNOWLEDGEMENTS}

Our thanks to all the patients who volunteered to participate in the study. To interns Ana Paula Oliveira de Souza and Larissa Oliveira Soares, who assisted during data collection. To the clinical research team at INTO, who assisted with scheduling logistics and physical support for receiving the participants.

All authors declare no potential conflict of interest related to this article.

CONTRIBUTION OF THE AUTHORS: All authors made significant individual contributions to this manuscript. RRV: Project, writing, intellectual concept, data collection and review; VRAC: Project, writing, intellectual concept, data collection and review; JDA: Project, writing, physician responsible for the surgeries; CTL: Project, data collection and review; LMS: Project, data collection and review; LEC: Project, writing, physician responsible for the surgeries; AGCB: Project, writing, physician responsible for the surgeries; CEF: Project, writing; RSPM: Project, physician responsible for the surgeries; UFG: Project data collection and review; SCS: Project, writing, intellectual concept, data collection and review.

\section{REFERENCES}

1. Negrini S, Donzelli S, Aulisa AG, Czaprowski D, Schreiber S, de Mauroy JC, et al. 2016 SOSORT guidelines: orthopaedic and rehabilitation treatment of idiopathic scoliosis during growth. Scoliosis Spinal Disord. 2018;13:3. doi: 10.1186/s13013-017-0145-8.

2. Stokes IA. Three-dimensional terminology of spinal deformity. A report presented to the Scoliosis Research Society by the Scoliosis Research Society Working Group on 3-D terminology of spinal deformity. Spine (Phila Pa 1976). 1994;19:236-48.

3. Riseborough EJ. The effects of scoliotic deformities on pulmonary function. Isr J Med Sci. 1973:9:787-90

4. McMaster MJ. Infantile idiopathic scoliosis: can it be prevented? J Bone Joint Surg $\mathrm{Br}$ 1983;65:612-7. doi: 10.1302/0301-620X.65B5.6643567.

5. Newton PO, Faro FD, Gollogly S, Betz RR, Lenke LG, Lowe TG. Results of preoperative pulmonary function testing of adolescents with idiopathic scoliosis. A study of six hundred and thirty-one patients. J Bone Joint Surg Am. 2005;87(9):1937-46. doi: 10.2106/ JBJS.D.02209

6. Johnston CE, Richards BS, Sucato DJ, Bridwell KH, Lenke LG, Erickson M, et al. Correlation of preoperative deformity magnitude and pulmonary function tests in adolescent idiopathic scoliosis. Spine (Phila Pa 1976). 2011;36(14):1096-102. doi: 10.1097/ BRS.0b013e3181f8c931.

7. Weinstein SL, Dolan LA, Spratt KF, Peterson KK Spoonamore MJ, Ponseti IV Health and function of patients with untreated idiopathic scoliosis: a 50-year natural history study. JAMA 2003:289(5):559-67. doi: 10.1001/jama.289.5.559.

8. Lonstein JE. Scoliosis: surgical versus nonsurgical treatment. Clin Orthop Relat Res 2006:443:248-59. doi: 10.1097/01.blo.0000198725.54891.73

9. Tsiligiannis T, Grivas T. Pulmonary function in children with idiopathic scoliosis. Scoliosis 2012;7(1):7. doi: 10.1186/1748-7161-7-7.

10. Karol LA, Johnston C, Mladenov K, Schochet P, Walters P, Browne RH. Pulmonary function following early thoracic fusion in non-neuromuscular scoliosis. J Bone Joint Surg Am. 2008;90(6):1272-81. doi: 10.2106/JBJS.G.00184.

11. Bridwell KH. Surgical treatment of idiopathic adolescent scoliosis. Spine (Phila Pa 1976). 1999-24(24):2607-16 doi: 10.1097/00007632-199912150-00008.

12. Weinstein SL, Zavala DC, Ponseti IV. Idiopathic scoliosis: long-term follow-up and prognosis in untreated patients. J Bone Joint Surg Am. 1981;63(5):702-12

13. Kim YJ, Lenke LG, Bridwell KH, Kim KL, Steger-May K. Pulmonary function in adolescent idiopathic scoliosis relative to the surgical procedure. J Bone Joint Surg Am. 2005;87(7):153441. doi: 10.2106/JBJS.C.00978.

14. Gitelman Y, Lenke LG, Bridwell KH, Auerbach JD, Sides BA. Pulmonary function in adolescent idiopathic scoliosis relative to the surgical procedure: a 10-year follow-up analysis. Spine (Phila Pa 1976). 2011;36(20):1665-72. doi: 10.1097/BRS.0b013e31821 bcf4c.

15. Barrios C, Pérez-Encinas C, Maruenda JI, Laguía M. Significant ventilatory functional restriction in adolescents with mild or moderate scoliosis during maximal exercise tolerance test Spine (Phila Pa 1976). 2005;30(14):1610-5. doi: 10.1097/01.brs.0000169447.55556.01.

16. Kearon C, Viviani GR, Killian KJ. Factors influencing work capacity in adolescent idiopathic thoracic scoliosis. Am Rev Respir Dis. 1993;148(2):295-303. doi: 10.1164/ajrc$\mathrm{cm} / 148.2 .295$

17. Alves VL, Avanzi O. Objective assessment of the cardiorespiratory function of adolescents with idiopathic scoliosis through the six-minute walk test. Spine (Phila Pa 1976). 2009:34(25):E926-9. doi: 10.1097/BRS.0b013e3181afd1b2

18. Lenke LG, White DK, Kemp JS, Bridwell KH, Blanke KM, Engsberg JR. Evaluation of ventilatory efficiency during exercise in patients with idiopathic scoliosis undergoing spinal fusion.
Spine (Phila Pa 1976). 2002;27(18):2041-5. doi: 10.1097/00007632-200209150-00014

19. Jeans KA, Lovejoy JF, Karol LA, McClung AM. How Is Pulmonary Function and Exercise Tolerance Affected in Patients With AIS Who Have Undergone Spinal Fusion? Spine Deform. 2017;5(6):416-23. doi: 10.1016/j.jspd.2017.04.001.

20. Lorente A, Barrios C, Burgos J, Hevia E, Fernández-Pineda L, Lorente R, et al. Cardiorespiratory Function Does Not Improve 2 Years After Posterior Surgical Correction of Adolescent Idiopathic Scoliosis. Spine (Phila Pa 1976). 2017;42(18):1391-7. doi: 10.1097/BRS.0000000000002105.

21. ATS. American Thoracic Society. ATS statement: guidelines for the six-minute walk test. Am J Respir Crit Care Med. 2002;166(1):111-7. doi: 10.1164/ajrccm.166.1.at1102.

22. Sinclair RCF, Batterham AM, Davies S, Cawthorn L, Danjoux GR. Validity of the 6 min walk test in prediction of the anaerobic threshold before major non-cardiac surgery. $\mathrm{Br} \mathrm{J}$ Anaesth. 2012:108(1):30-5. doi: 10.1093/bja/aer322.

23. Wesolowski S, Orlowski TM, Kram M. The 6-min walk test in the functional evaluation of patients with lung cancer qualified for lobectomy. Interact Cardiovasc Thorac Surg 2020;30:559-64. doi: 10.1093/icvts/ivz313.

24. Cobb JR. Outline for the study of scoliosis. Inst Course Lect AAOS. 1948:5:261-75

25. Matsudo S, Araújo T, Matsudo V, Andrade D, Andrade E, Oliveira LC, et al. Questionário internacional de atividade física (ipaq): estupo de validade e reprodutibilidade no Brasil. Revista Brasileira de Atividade Física \& Saúde. 2001;6(2):5-18. doi: 10.12820/rbafs.v.6n2p5-18.

26. Borg G. Psychophysical scaling with applications in physical work and the perception of exertion. Scand J Work Environ Health. 1990:16 Suppl 1:55-8. doi: 10.5271/sjweh.1815.

27. Rufino R, Costa CH, Antão VCS, Pinheiro GA, Jansen JM. Relação Envergadura/Altura: Um Valor para Estudos Espirométricos em Brasileiros. Pulmão RJ. 1996;5:40-4.

28. Miller MR, Hankinson J, Brusasco V, Burgos F, Casaburi R, Coates A, et al. Standardisation of spirometry. Eur Respir J. 2005:26(2):319-38. doi: 10.1183/09031936.05.00034805.

29. Knudson RJ, Lebowitz MD, Holberg CJ, Burrows B. Changes in the normal maximal expiratory flow-volume curve with growth and aging. Am Rev Respir Dis. 1983;127(6):725-34 doi: 10.1164/arrd.1983.127.6.725

30. Souza RB. Pressões respiratórias estáticas máximas. J Bras Pneumol. 2002:28 (Supl3):S155-65.

31. Neder JA, Andreoni S, Lerario MC, Nery LE. Reference values for lung function tests. II. Maximal respiratory pressures and voluntary ventilation. Braz J Med Biol Res. 1999;32(6):71927. doi: 10.1590/s0100-879x1999000600007

32. Soares MR, Pereira CAC. Teste de caminhada de seis minutos: valores de referência para adultos saudáveis no Brasil. J Bras Pneumol. 2011:37(5):576-83. doi: 10.1590/S180637132011000500003

33. Johnston CE, Richards BS, Sucato DJ, Bridwell KH, Lenke LG, Erickson M, et al. Correlation of preoperative deformity magnitude and pulmonary function tests in adolescent idiopathic scoliosis. Spine (Phila Pa 1976). 2011;36(14):1096-102. doi: 10.1097/ BRS.0b013e3181f8c931

34. Martínez-Llorens J, Ramírez M, Colomina MJ, Bagó J, Molina A, Cáceres E, et al. Muscle dysfunction and exercise limitation in adolescent idiopathic scoliosis. Eur Respir J. 2010;36(2):393-400. doi:10.1183/09031936.00025509.

35. Koumbourlis AC. Scoliosis and the respiratory system. Paediatr Respir ver. 2006;7(2):15260. doi: 10.1016/j.prrv.2006.04.009

36. Araujo GS, Saraiva BMA, Sperandio EF, Toledo Filho M, Freira JM, Gotfryd AO, et al. Functional capacity in adolescent idiopathic scoliosis during the postoperative period. Rev Bras Med Esporte. 2019;25(2):127-32. doi: 10.1590/1517-869220192502185369. 